Article

\title{
"One's Own Body of Pure Channels and Elements": The Teaching and Practice of Tibetan Yoga at Namdroling
}

\author{
Naomi Worth
}

Citation: Worth, Naomi. 2021. “One's Own Body of Pure Channels and Elements": The Teaching and Practice of Tibetan Yoga at

Namdroling. Religions 12: 404.

https://doi.org/10.3390/rel12060404

Academic Editor: Brooke Schedneck

Received: 9 March 2021

Accepted: 5 April 2021

Published: 31 May 2021

Publisher's Note: MDPI stays neutral with regard to jurisdictional claims in published maps and institutional affiliations.

Copyright: (C) 2021 by the author. Licensee MDPI, Basel, Switzerland. This article is an open access article distributed under the terms and conditions of the Creative Commons Attribution (CC BY) license (https:/ / creativecommons.org/licenses/by/ $4.0 /)$.
Department of Religious Studies, University of Virginia, Charlottesville, VA 22903, USA; nw3ca@virginia.edu

\begin{abstract}
The Tibetan yoga practice known as "winds, channels, and inner heat" (rtsa rlung gtum mo) is physically challenging, and yet is intentionally designed to transform the mind. This chapter explores the relationship between Buddhist doctrine and this physical practice aimed at enlightenment through the teachings of a contemporary yoga master at Namdroling Tibetan Buddhist Monastery and Nunnery in Bylakuppe, Karnataka, South India. This ethnographic profile exemplifies the role of a modern Tibetan lama who teaches a postural yoga practice and interprets the text and techniques for practitioners. While many modern postural yoga systems are divorced from religious doctrine, Tibetan Buddhist yoga is not. This essay highlights three key areas of Buddhist doctrine support the practice of Sky Dharma (gNam chos) yoga at Namdroling: (1) The history and legacy that accompany the practice, which identify the deity of Tibetan yoga as a wrathful form of Avalokiteśvara, the Buddha of compassion; (2) The role of deity yoga in the practice of Tibetan yoga, where the practitioner arises as the deity during yoga practice, an all-consuming inner contemplation; and (3) The framing of Tibetan yoga within the wider philosophy of karma theory and its relationship to Buddhist cosmology. Practitioners of Tibetan yoga endeavor to burn up karmic seeds that fuel the cycle of rebirth in the six realms of samsāra. In Tibetan yoga, the body acts in service of the text, the philosophy, and the mind to increasingly link the logic of texts to experience in meaningful ways.
\end{abstract}

Keywords: Tibetan yoga; modern yoga; modern Buddhism; monastic life; Tibetan Buddhism; Buddhist contemplation; tantric body; subtle body

\section{Introduction}

Contemporary Tibetan Buddhist monasteries are often seen as centers for scholastic learning and ritual performance with few opportunities for meditation (McMahon 2009; Dreyfus 2003) ${ }^{1}$. In contrast, Namdroling Monastery and Nunnery institutionally prioritizes the integration of both philosophy and contemplative practice under one roof. Life in refugee camps has fostered a great deal of sharing among the sects of Tibetan Buddhism, and indeed contemporary Nyingma institutions including Namdroling engage in scholastic practices such as debate more than ever ${ }^{2}$. However, the vestiges of the Nyingma sect as the clan of yogis ${ }^{3}$ in Tibet continues to pervade this lineage ${ }^{4}$. At Namdroling, monks and nuns really do meditate, and in fact the monastery runs dual scholastic and contemplative curricula throughout the year. This essay takes a close look at th yoga of winds, channels, and inner heat (rtsa rlung gtum mo), a relatively uncommon form of Tibetan contemplation that is offered annually at the monastery. The practice has recently come to be known as "Tibetan yoga." Ethnographic accounts of its main teacher at the monastery, Lama Dorje Wangpo are combined with teachings on Tibetan yoga given during the annual, month-long retreats at Namdroling.

The purpose of this article is to show how Tibetan yoga is oriented around the mind via creation and completion stage contemplations. The technical term for Tibetan yoga is tsalung tummo (rtsa rlung gtum mo), which translates as winds, channels, and inner heat [yoga $]^{6}$. Despite being a heavily bodily-oriented technique like other forms of modern postural yoga, Tibetan yoga stands out in that it is not divorced from its religious and historical 
tradition. Sky Dharma ( $g$ Nam chos) yoga taught at Namdroling is embedded within the history, mythology, and philosophy of Great Perfection Buddhism. Practitioners are taught to understand the poses and contemplations through the lens of Tibet's rich history and culture, and the supporting narratives shape the ways the practice is interpreted. Tibetan yoga's emphasis on the mind can be seen through its reliance on a Tibetan philosophical worldview, most specifically on karma theory as it relates to Buddhist cosmology. Sky Dharma yoga is unique among contemporary postural yoga systems in that while the body is a main tool in the practice, it works in service of the mind to experience classical yoga texts in real ways.

\section{Modern Tibetan Buddhist Postural Yoga}

Namdroling Monastery and Nunnery sits in the Tibetan refugee camp of Bylakuppe just two hours from a popular global hub for modern Ashtanga yoga in Mysore, Karnataka. Unlike Mysore's fame among contemporary yoga practitioners, Namdroling monks, nuns, and Tibetan refugees have been quietly practicing Sky Dharma (gNam chos) (Mi 'gyur rdo rje and Kun bzang shes rab 200), the set of contemplative manuals revealed by Namchö Mingyur Dorje (gNam chos mi ' $g y u r$ rdo rje; 1645-1667) in Tibet, since 1973. The visionary lama Penor Rinpoche (1932-2009) founded Namdroling in 1963 four years after he travelled on foot from Tibet to India to escape Chinese military rule. The majority of his travel companions died along the way. While Namdroling's origins are traumatic, much of that story is unfamiliar to the young monks and nuns who live there today.

I went to South India to research the second level of Migyur Dorje's three-tiered contemplative program, a monthlong retreat on Tibetan yoga ${ }^{7}$. I planned to explore the relationship between the practice of Tibetan yoga and the related tantric theory of embodiment popularly known as the subtle body, whose main features are channels, winds, and seminal essences (rtsa rlung thig le). Cakra-s ('khor lo) also feature prominently.

In the world of modern postural yoga, it is not common knowledge that Tibetan Buddhism has an ancient tradition of yoga that continues to be practiced today. Historically, Tibetan Buddhist monasteries provided homes for the stable transmission of practice techniques across generations, and the yoga tradition at Namdroling is a prime example. Sky Dharma yoga was revealed in the seventeenth century by the mystical figure Migyur Dorje and commented on by his disciple and caretaker Karma Chakmé (kar+ma chags med, 1613-1678). These texts are followed precisely at Namdroling, a living lineage carried from Tibet to India in 1959 during one of the mass exoduses when Tibetans fled Chinese military rule. Thus, this research opens a window onto what a continuous practice lineage might have looked like in seventeenth-century Tibet when yogins followed the same detailed set of instruction manuals. However, the Sky Dharma practices at Namdroling unfold in the significantly different cultural context of South India in modern times. Migration and change are constant features of yoga traditions, much to the chagrin of contemporary yoga enthusiasts who crave essentialized and mystical origins to modern postural yoga lineages. However, spiritual seekers would be quite pleased with the way the monastic system in Tibet, combined with Tibet's relative isolation ${ }^{8}$ from political interference from outsiders for hundreds of years, allowed for the preservation of the textual lineage of Sky Dharma yoga.

If Tibetan yoga is such an ancient yet ongoing tradition, why do we not we know about it? Several factors contribute to its lack of fame. First, Tibetan yoga is a secret practice that requires tantric initiation. The secrecy factor makes the monks, nuns and lay people with initiation close mouthed about the practice. Second, it is usually practiced in retreat. Such experiences are a far cry from the "yogacation" ${ }^{\prime}$ model so popular in the contemporary yoga world. Tibetan yoga is practiced in the same format in which strict meditation retreats are conducted. Practitioners typically undertake four long contemplative sessions per day.

Unlike modern yoga retreats, Tibetan yoga retreats have not picked up on the luxury aspect. Quite the contrary. At Namdroling, the retreats are offered freely or by donation within the monastery walls. While the setting is idyllic, the food is basic at best, there is 
no alcohol and no beach, and the genders are separated. Another factor that differentiates Tibetan yoga from other modern yoga traditions is that it does not include much stretching. While it is physically dynamic and potentially improves health and cardiovascular fitness, it involves a significant amount of jumping and landing in a seated position (lotus or half-lotus), which can be hard on the knees and not relaxing ${ }^{10}$. Finally, similar to other forms of Tibetan Buddhist contemplation, Tibetan yoga requires extensive visualizations of deities or the tantric body endowed with Buddhist principles and doctrine. This living lineage comes with its own terms, and is resistant to conforming to contemporary yoga conventions or trends. It is a deeply religious practice, and does not pretend to be secular.

Being part of a prescriptive contemplative tradition makes Tibetan yoga stand out among modern yoga systems ${ }^{11}$. Tibetan yoga is specific, clear, and unwavering in the ways that it directs the mind. Each posture is accompanied by a prescribed mental contemplation that refers back to the religious semiotics of Tibetan Buddhist tantra. This guides the practitioner toward Buddhist goals, namely mental purification of the five afflictions (attachment, aversion, ignorance, pride and jealousy), the accumulation of merit, and eventually enlightenment itself. Cognitive procedures standard to Tibetan Buddhist contemplation such as guru yoga, purification through imagined and real tantric empowerments, and visualization of the tantric body made of channels, winds, and seminal essences are omnipresent during the performance of the physical sequences. All of this is accompanied by simultaneous breath retention. Thus, while Tibetan yoga involves the execution of complex series of postures and breath retentions, the highly prescribed visualizations and accompanying rituals before, during, and after the practice constantly orient the mind to the reification and internalization of Buddhist philosophy.

\section{Tibetan Hațayoga}

Tsalung tummo (winds, channels, and inner heat yoga) is a Tibetan Buddhist parallel to Indian hathayoga, a term that applies to "physical methods used for religious ends" (Mallinson 2020). Yoga scholar James Mallinson recently made it clear that early Buddhist vajrayanna literature is included in the hathayoga corpus of literature. The early-medieval Indian Buddhist texts that he cites as part of the hathayoga lineage share goals with the Sky Dharma yoga techniques practiced at Namdroling, most notably the raising of bodhicitta up the central channel. Mallinson focuses on the sexual practices described in the Indian Buddhist vajrayāna system. The Sky Dharma tradition itself declares that inner heat yoga and sexual yoga are alternatives for each other, but that inner heat yoga is more accessible and less prone to human error because it avoids sexual engagement, both real or imagined. This also makes it better suited for monastics with celibacy vows.

For this research, I participated in two month-long Tibetan yoga retreats between February 2018 and August 2019. When I arrived at Namdroling, I had no firsthand experience of Tibetan yoga. However, my years of engagement with the philosophy and practices of both modern yoga and Buddhism equipped me with some expectations about the tantric body, including about pranna (rlung), the energetic life force central to its functions. The tantric body is also known as the subtle body, a quasi-material level of embodiment (Samuel and Johnston 2013) comprised of three main features: winds, channels, and seminal essences. Kerry Skora describes the subtle body as "where Reality enfolds at once both Consciousness and matter" (Skora 2020). In practices designed to manipulate the subtle body directly such as Tibetan yoga, the breath (rlung; Skt: vāyu) and the body provide the main supports for the scripted contemplations. In between the retreats, I read about the philosophy of the mind-body connection associated with Tibetan yoga under the guidance of Namdroling professors (two Khenpos ${ }^{12}$ and a Loponma) ${ }^{13}$ for nine months ${ }^{14}$.

This article focuses on the exchanges I had with Namdroling's in-house yoga master, Lama Dorje Wangpo ${ }^{15}$. The Buddhist doctrine laid out in Sky Dharma, along with Lama Dorje's explanations, showcase how the categories of mind and body work together under the umbrella of yoga practice in service of the generation of specific states of mind. The 
mind and body are directed in certain actions, and feelings, emotions, and realizations should result. In Tibetan Buddhism, the mind is primary over the body, both in philosophy and in lived experience. The role of the teachers is largely to define the parameters of the practice and its effects, and to serve as examples.

As the resident yoga master, Lama Dorje acts as mediator between the text and the practitioners. He knows the intricacies of the practice as presented in the Sky Dharma manual, and plays an instrumental role in interpreting the ways practitioners at Namdroling perform the postures ${ }^{16}$. As a teacher, he is an important conduit through which doctrine is delivered to the community of practitioners. Because of his public role, he is highly motivated to adhere to the Sky Dharma manuals and other sources of Nyingma Buddhist philosophy.

One of the Namdroling Khenpos recounted to me that there are two types of dharma (Buddhist doctrine). The first is the actual teachings, which are relatively easy to trace through the extensive textual history of Buddhism. The vast majority of the academic field of Buddhist studies has been dedicated to the close examination of texts and philological works that unpack their meaning. The second type of dharma is the realizations and cessations in the minds of dharma practitioners ${ }^{17}$. Lama Dorje offers a glimpse into the mind of a dharma practitioner with a significant amount of experience in Tibetan yoga.

\section{Lama Dorje's Story}

Lama Dorje Wangpo (born 1971) is an artist. He is one of those rare people who has both natural talent and extensive training. He is handsome and full of grace. In addition to being the main yoga teacher at Namdroling, he teaches lama dancing and oversees the creation of intricate sand mandalas. He often performs the chöd ritual, and his chanting is breathtaking. When he is not teaching, he laughs a lot, jokes with the other monks, and naturally has the demeanor of a surfer. He is cool. He also has a timid side.

Lama Dorje has undertaken the tsalung retreats more than anyone else I met at Namdroling. He is the default tsalung teacher in that he always assumes the role of teacher when a course is offered and he is present. I did not have the opportunity to take his classes in India because he taught the monks, and because of the separation of genders, I was performing the tsalung retreat with the nuns. However, he met with me around twice a week to answer my research questions. He has been teaching tsalung internationally since he graduated from the monastic college in 1999. He typically spends a few months annually at Namdroling to teach tsalung.

Lama Dorje was born in Pema Köd, "the hidden land shaped like a lotus" (Baker 2004). Pema Köd is one of Tibetan Buddhism's most holy sites, a location so remote and deep in the Himalayas that legend claims it has been preserved intact since the time when Guru Rinpoche himself dwelled there. Pema Köd is extremely difficult to access. Even today, it requires extensive overland travel followed by a two-day trek on foot, or you can take a helicopter. It is one of the twenty-four sacred pilgrimage sites said to be located in the tantric body in tsalung teachings, including in Sky Dharma. Such sacred sites are examples of how the inner tantric body is a mirror reflection of the external world.

Lama Dorje is considered to have good karma, i.e., the correct circumstances for practice. This is evidenced by the culture of yogis in Pema Köd that surrounded his early life. As a child, he knew yogis who talked about and performed tsalung practice. He would listen to them and emulate their jumping techniques with his friends, in particular his childhood best friend who is a well-known tulku in the Dudjom Tersar tradition. The two of them used to chase each other by hopping around in the full-lotus position, using the raised door jam in his house as a hurdle. In the Tibetan tradition, all these circumstancesbeing born in a holy place such as Pema Köd, being surrounded by practicing yogis and learning Buddhism through their example, and having a tulku as a childhood companionwould be interpreted as a strong karmic connection with the practice of Tibetan yoga and esoteric Buddhism. 
He was able to sustain his good karma by accumulating merit through the traditional means: the accumulation of spiritual practices. At just nine years old, he performed "the five hundred thousand" (bum lnga), the accumulation of repetitions of the Foundational tantric practices alongside his tulku friend. At age eleven, he completed the Dudjom Tersar version of these practices as well. Thus, he had performed the Foundational tantric practices twice before he became a monk. The place in his old wooden house where they performed their prostrations still has imprints in the wood. When he later became a monk, he performed the Foundational tantric practices twice more, for a total of four times.

Even with such favorable circumstances for practicing the dharma, like many practitioners, historical and contemporary alike, Lama Dorje was motivated to take up the dharma more seriously because of his own suffering. His father was what Lama Dorje calls "strict". When Lama Dorje had difficulty understanding his schoolwork, his father would hang him upside down by his feet, beat him until he bled, and then put chili powder on the wounds. One time, his father hung him upside down and went looking for nettle, a plant with stiff hairs on the branches that releases a stinging chemical when touched. He managed to break the ropes and run away. These adverse experiences only increased his focus on the dharma as a refuge from the suffering of life.

At age thirteen in 1985, his father went to Bodh Gaya, the famous location of the Buddha's enlightenment and a popular pilgrimage site among Buddhists in India. The Dalai Lama was giving the Kālacakra empowerment. Lama Dorje told his father he wanted to become a monk and was allowed to accompany him. Penor Rinpoche was in attendance at the event, and a Namdroling monk named Lopon Pema Rigdzin made the request to ordain on Lama Dorje's behalf. When Penor Rinpoche accepted, he was so happy that he told all his friends from his village. Together, sixteen of them became monks, although today only two or three are still ordained.

Lama Dorje began his education in Namdroling's dratsang (grwa tsang), the equivalent of a primary school, and later entered the monastic college. Altogether, his education at Namdroling took seventeen years. During that time, he had the distinct feeling that he was under the care and protection of Penor Rinpoche. One time he got sick with some type of pox, and Penor Rinpoche himself came to his side, carried him to the car, and drove him and a few other sick monks to the doctor. Dorje vomited in the car on the way.

Lama Dorje is of the opinion that it is fortunate that in the seventeen years that he studied at Namdroling, he did not have money to go into town. Some monks are well resourced with pocket money from their families or donors. Without pocket money, he had to stay inside the monastery where food and housing are provided, but no frills. This gave him both the time and resources to practice the arts that are the cornerstone of his teaching career.

\section{Background: Tibetan Buddhist Tantric Postural Yoga}

Although Tibetan yoga is not common and there are many barriers to entry, Tibetan Buddhism's postural yoga tradition is more prevalent among Tibetan Buddhist monastics and yogis than one might expect. So why have we not we heard about Tibetan yoga in the same ways that we know about Indian yoga?

One reason is that Tibetan Buddhism is pervasively characterized by tantra, a form of practice that is guarded as an "open secret". It is open in that tantra is the prevalent practice mode of Tibetan Buddhism. Tantra is ubiquitously seen in Tibetan Buddhism's images, mantras, ritual gestures, and semiotics. However, access to tantric practices is guarded through both prerequisites and initiation. Without those, outsiders pick up on what Buddhism emphasizes outwardly, the non-tantric Buddhist teachings on wisdom and compassion. However, tantric practices are the main Tibetan techniques to generate wisdom and compassion. Tibetan yoga is one among many of Tibetan Buddhism's secret practices that require preliminary practice and initiation.

Such tantric forms of Buddhist contemplation often use the body or tantric body as the primary site for transformation. Over the course of the elaborate contemplative process 
described across the three books that comprise the Sky Dharma cycle of teachings, tantric contemplations make use of the body as a tool in both real and imagined ways. The main body-oriented practices in Sky Dharma include the transference of consciousness out of the body upon death (pho ba); severance (chod) meditation, where one visualizes chopping up one's own body and serving it as nectar to enlightened beings; channels, winds, and seminal essences practice such as Tibetan yoga, or its sister practice, sexual yoga; and visioncentered meditations where one uses light to see Buddhas that manifest out of the tantric body via the eyes into the sky. These contemplative techniques exemplify "philosophical tantra", where praxis systems are unremittingly entangled with Buddhist philosophy. Such techniques showcase Tibetan Buddhist praxis systems' deep commitment to philosophy. While it is possible to practice Tibetan yoga without an education in philosophy, the monks and nuns at Namdroling constantly make use of their formal education in Buddhist philosophy in how they interpret and perform the practices. Their philosophical training is what makes the practices meaningful for them.

Another reason the yoga of winds, channels and inner heat is not popular even among Tibetan Buddhists is because it is quite physically challenging. It involves bodily feats that not everyone cares to endeavor, or they simply lack the physical fitness to do so. ${ }^{18}$ Some of the monastics and lay people at Namdroling told me they avoid Tibetan yoga due to concerns for their health. On Namdroling's monastic campus, the monks and nuns lack the required space and privacy to practice outside of the retreat setting. In Tibetan Buddhism at large, a plethora of other contemplative practices may take priority based on the culture of a lineage. Tibetan Buddhism is simply not experiencing a yoga craze like much of the rest of the world. At the same time, the Khenpos at Namdroling taught that Sky Dharma yoga is related to Indian hatha yoga.

As the middle component of Migyur Dorje's stage-wise contemplative path to enlightenment, postural yoga and sexual yoga are treated as alternatives to one another in that they both take advantage of the body's gnostic resources, i.e., the wisdom winds. These are considered important but optional stages on the path to enlightenment. In the New (gsar ma) sects of Tibetan Buddhism, such completion stage practices are the pinnacle of subtle body techniques undertaken just prior to complete enlightenment. However, in the Great Perfection tradition of the Nyingma sect, these are considered indirect compared to the unique forms of Great Perfection contemplation, namely breakthrough (khregs chod) and crossing over (thod rgal). In the Great Perfection, the main purpose of these bodycentered contemplations is to remove obscurations to enlightenment in the form of karmic hindrances that are stored in the body. Together, the postural and sexual yogas are in the anuyoga class of tantra according to the ninefold Nyingma classification system of vehicles to enlightenment, although they employ mahāyoga techniques as well. Tibetan Buddhist postural yoga, and its sister practice sexual yoga, are the trademark techniques of anuyoga, the vehicle just beneath the Great Perfection, the highest or Supreme Yoga (atiyoga).

Tsalung trulkhor received worldwide attention in Alexandra David-Neel's 1929 book Magic and Mystery in Tibet. Her tales of Tibetan yogis who demonstrated superhuman powers by drying wet blankets with only their naked bodies in the freezing cold of the high mountains gave tsalung the reputation as a siddhi practice. This yogic superpower was particular to the cold temperatures in Tibet where yogis needed to stay warm through the winter, especially during long retreats in remote areas. Indeed, inner heat yoga generates heat in the body. However, the monks and nuns at Namdroling continue to undertake the practice in exile in South India where it is quite hot, and they claim that its purpose is not only to raise heat, but rather to attain enlightenment.

Namdroling was founded in 1963 as the Indian branch of the Tibetan Palyul monastic lineage, founded in 1665. They held their first Sky Dharma retreats in 1973. Migyur Dorje's Sky Dharma root verses, accompanied by his caretaker and guardian Karma Chakmé's commentaries, are the revelations that the Palyul monastic lineage have used as the textual basis for contemplative practice retreats since the seventeenth century. 
The treasure revealer Migyur Dorje has a huge presence at Namdroling. Mugsang Tulku, one of the three main tulkus at Namdroling, is a living reincarnation of Migyur Dorje. He frequently resides at the monastery when he is not visiting one of the other Palyul centers abroad. There is also a Migyur Dorje stupa at Namdroling that contains some of his relics. This is a favorite site where local Tibetans, Bhutanese, Nepali and Indian lay people circumambulate alongside the monastics. The accumulation of 100,000 passes around the stupa is said to bring health benefits, and the pursuit of health through this method is more popular at Namdroling than Tibetan yoga.

In the monastery, the practice of Tibetan yoga goes by two names: tsalung tummo (rtsa rlung gtum mo), which translates as "winds, channels, and inner heat", or tsalung trulkhor (rtsa rlung 'phrul 'khor), "turning around illusion with the winds and channels". Some scholars (For example, Chaoul (2009) and Dr. Nida Chenagtsang (2020)) translate the word trulkhor ("phrul 'khor) as "Magical Movements", but Migyur Dorje invokes a slightly different spelling while maintaining the same phoneme to subtly shift the meaning. Trulkhor ('khrul 'khor) in the Sky Dharma teachings can be translated as "turning around illusion".

Most monks and nuns will not dedicate their lives to tsalung. To do so, they would have to practice on their own or join a community of yogins outside of Namdroling. Many practice only for one month, which is in line with the way students learn within the monastic environment. In many ways, the monks and nuns become generalists in Buddhist philosophy and practice while at the monastery. If they want to go further, they seek out teachers and communities outside the monastery.

Sky Dharma is part of the uniquely Tibetan Buddhist literary genre of terma (gter $m a)$, which are revelations said to have been hidden in Tibet by Guru Rinpoche and his consort/wife Yeshe Tsogyal. Migyur Dorje revealed the Sky Dharma terma when he was only sixteen years old. It is a "mind treasure" (dgongs gter), meaning that it was revealed to him directly in a vision, in this case of a wrathful form of the Buddha of compassion. The other popular type of terma are earth treasures (sa gter), which are hidden around Tibet behind rocks and other physical locations. The terma tradition continues today: revelations still happen. The Namdroling lamas liken terma to dharma which is like fresh milk, rather than old milk. Terma provide a mechanism by which Buddhas can continue to teach, bringing new material into the lineage. Such revelations are considered to be words of the Buddha. As divine revelations, they are ultimately timeless.

The other special genre that Sky Dharma falls into is literature on the stages of the path to enlightenment. Many Tibetan masters over the years have laid out the gradual path using their own religious sub-sect's particular vernacular, worldview, and contemplative techniques, and this is one of them. The stages model invites practitioners to gradually construct both worldviews and contemplative skills. The layering of beliefs and skills build upon one another, which is particularly evident in the experiences of practitioners circumscribed by the Sky Dharma path at Namdroling. One establishes a solid foundation in tantric contemplative techniques in the Foundational (sngon 'gro) phase. They further prepare themselves with tsalung, which purifies karma and accumulates merit. Finally, they endeavor to see the nature of the mind in Great Perfection meditations. It is said to be possible to attain the state of enlightenment at any point along the way.

When Lama Dorje graduated from Namdroling in 1999, he presented Penor Rinpoche with a beautiful mandala he had painted. Penor Rinpoche checked the accuracy and approved, blessing it and allowing him to keep it. Soon after his graduation, Penor Rinpoche requested that he go with him on his teaching tours around the globe. It was a special honor to be asked so quickly-most monks had to wait at least a few years, if asked at all. That year, Lama Dorje prepared the Kālacakra sand mandala three times: in Singapore, Canada, and at Namdroling. He traveled with Penor Rinpoche from 1999 until his passing in 2009, and continues to teach worldwide today. Lama Dorje sees the time spent with Rinpoche as an honor, and believes that he carries a seed of his teachings inside of him that will continue to grow with practice. 
While Penor Rinpoche alone used to transmit the Sky Dharma teachings at Namdroling, nowadays the highest lama on campus gives the empowerment (dbang) and textual transmission ('khrid). Practitioners must literally hear the text read aloud by a person who holds the lineage as a necessary prerequisite to be able to read and practice the text themselves. Each year, all three levels (see next section) of the Sky Dharma retreats run concurrently starting two weeks after Tibetan New Year (lo gsar).

\section{The Inner Methods of Tibetan Yoga: Generation and Completion Stage Tantra}

The first level of retreat, the Foundational tantric practices (sngon 'gro), is mainly comprised of beginner-level mahāyoga techniques, i.e., generation stage (bskyed rim) tantric contemplations that involve elaborate visualizations. The Sky Dharma Foundational practices explain basic Buddhist philosophy, and also train practitioners in the arts of fundamental tantric meditation techniques such as guru yoga, mandala offerings, and Vajrasattva purification. The first lessons are in basic Buddhist philosophy, known as the "four thoughts that turn the mind". These are contemplations on (i) the preciousness of being born as a human, (ii) death and impermanence, (iii) the sufferings of cyclic existence, and (iv) the law of karma, or cause and effect. Through philosophy teachings, the Namdroling lamas guide practitioners to analyze and adopt these basic Buddhist views, which they claim are universal among all forms of Buddhism worldwide.

The main Foundational practice techniques are known as the "extraordinary preliminaries". Here, practitioners begin their training in tantric contemplation and ritual, which separates these techniques from the shared, universal Buddhist principles found in the common preliminaries. The tantric preliminaries highlight one's ability to access their own tantric body. The "transference of consciousness" (pho ba) is a preparation for the time of death where one rehearses ejecting their own consciousness out of the crown of the head to rebirth in a pure land. Practitioners are instructed to perform this at the actual time of death should they die an accidental death and have no opportunity for other techniques.

The Foundational practices retreat prepares practitioners for Tibetan yoga in several ways. Conceptually, there are prayers that posit winds, channels, and seminal essences as the inner level of the Three Jewels of refuge. Amidst numerous prayers and recitations that must be recited daily, these lines are almost subliminal but they include the tantric body as a basic component of a Buddhist worldview. This is a back-door introduction to the tantric body, which features as part of tantric Buddhism's taxonomy of ontological categories, but at this stage of practice they remain largely unexplained. For example, this is one of the many daily prayers that discusses the tantric body:

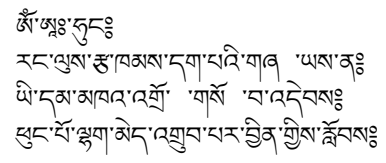

\section{OM AH HUNG}

In the immeasurability of one's own body of pure channels and elements,

I supplicate to the tutelary deities and female sky-goers.

May (you) bless me to attain the dissolution of the aggregates ${ }^{19}$.

The Foundational practices make a person a skilled adept in tantric visualizations and also Buddhist philosophy. In that way they are like "tantric boot camp", although in reality they take even longer than boot camp. Dedicated monks, nuns, and lay people at Namdroling complete 100,000 of each of five Foundational practices, for a total of 500,000 repetitions known as "the five-hundred thousand" (bum lnga), over the course of six months. The practices are: refuge (kyab dro; Skt. sarana) in the Three Jewels; the generation of bodhicitta (byang chub kyi sems; Skt. bodhicitta); mandala offering (mandal 'bul ba); Vajrasattva purification ( $r$ do rje sems $d p a$ '); and guru yoga (bla ma'i rnal 'byor). For those unable to commit themselves full-time for six-months, this process can take years. The goals of the Foundational practices are to develop an attitude of renunciation toward 
worldly life, faith in the Buddhist teachings, and an enduring wish to attain enlightenment for the sake of all sentient beings. According to one Namdroling monk, "without these factors, enlightenment is impossible ${ }^{\prime 20}$.

This training in tantric visualization is carried forward into the second level, the yoga of winds, channels, and inner heat (rtsa rlung gtum mo). While the ability to visualize deities is integral to this stage, the main training is in anuyoga, or completion stage (rdzogs rim) tantra. Here, students learn a detailed map of the cakra-s, channels, winds, and seminal essences. The main mental techniques are visualizations of the central channel and deity yoga. These common tantric practices are combined with physically challenging postures (āsana) and long breath retentions (prānāyāma). In the anuyoga stage, yogic techniques center on both the coarse body and the tantric body in order to manipulate the body's energies. The goal for practice is to clear away karmic obstacles stored into the body and tap into the inner buddha nature, which is hidden deep in the recesses of the tantric body.

A hallmark of anuyoga techniques is that they take advantage of Buddha body theory, which states that ordinary minds have a natural state-the mind-as-such (sems nyid) tantamount to a Buddha's mind present throughout the body. This "primordial awareness" (ye shes) of a Buddha flows as embodied awareness through the tantric body's channels. The tantric body maps the mind across the body via three pan-tantric elements: channels, winds, and seminal essences (rtsa rlung thig le; Skt: nadī vāyu bindu). Cosmologically, the wisdom winds (ye shes kyi rlung) emerge out of the primordial Buddha Samantabhadra (Kun tu bzang po). At the level of the individual, the karmic winds obscure the wisdom winds. The yogin's task is thus to reveal the natural presence of the wisdom winds by clearing away the karmic body through yogic techniques (Higgins 2012). Ultimately, the human body is the problem: it is made of karma (las) and habitual tendencies (bag chags; Skt: vāsan̄a).

The use of the tantric body model comes full circle in atiyoga, "supreme yoga". In the third level of the Sky Dharma retreats, the yogin engages in the Great Perfection's most well-known path of meditation, the practice of "crossing over" (thod rgal). Here, one continues to employ the tantric body model learned in tsalung tummo, but it is no longer the main focus. The contemplative path shifts to techniques where the body is once again the central location for the purification of karma in another round of preliminary practices known as "transforming samsāra into nirvāna" ('khor 'das ru shan) (van Shaik 2004).

The main Great Perfection practice consists of open-eye meditations-mostly sky gazing - that bear witness to light and color as form. The interpretation of forms is driven by the hermeneutical training that came before, especially the visualization of buddhas. Relying on tantric body theory, the meditations are performed while holding postures that mimic animals and other beings, such as a lion, elephant, and sage. The postures are meant to aid in the production of visions, are static, and are held for as long as possible. Practitioners might see buddhas in the floaters and other shapes that naturally appear in the field of vision, forms they have been training to see since the earliest stages of tantric training in practices like deity yoga and visualization of the mandala field of merit. The heart is said to be the seat of the universal ground ( $k u n$ gzhi; Skt: ālaya) of consciousness, which in the Great Perfection is the juncture where inner Buddha nature manifests outwardly through the eyes (Dudjom Rinpoche 2002). The recognition of one's inner buddha nature is enlightenment.

Atiyoga's predominant motif is the rhetoric of relaxation, and regardless of the stage of practice, it pervades the culture at Namdroling. Once when introduced to a monk, he said, "Welcome to Namdroling. Time to relax"!21 The aim of all these practices is to drop conceptual thoughts and relax into the natural state of "self-radiant awareness" (See Hatchell 2014). For Great Perfection Buddhism, normal conceptuality (rnam par rtog $\mathrm{pa}$ _- the ongoing stream of thought-indirectly perceives objects through a veil of delusion. Therefore, it is the cause of human suffering. Atiyoga contemplations use somatic experience to navigate toward non-conceptual, direct perception ${ }^{22}$. 


\section{The Living History of Tibetan Yoga}

Of all the people that I spoke with at Namdroling, Lama Dorje is the most knowledgeable about tsalung practice in its theoretical, historical, and practical aspects. He also has a lot of experience teaching "Westerners", ${ }^{23}$ and as I was the only Westerner and the only non-monastic practicing with the nuns, he granted me interviews during the two tsalung retreats I attended. My particular social position likely influenced the amount of detail I was given, and also the types of information I was privy to. What follows are explanations of tsalung tummo practice from Lama Dorje. Most of it can be cross-referenced to the Sky Dharma manuals. Lama Dorje usually spoke to me in half Tibetan and half English. I allowed my own doubts and interests as a practitioner to inform the questions I asked. The first time I attended the tsalung tummo retreat, it was a grueling experience. The second time I attended, I was able to relax and had some basic skills to work with.

One of the first questions I asked Lama Dorje was: why did Avalokiteśvara, the Buddha of Compassion, manifest in his wrathful form as the central deity of tsalung practice? He responded by recounting the history found in the first lesson of the Sky Dharma Tsalung Manual (Mi 'gyur rdo rje and Kun bzang shes rab 2007). Like many Tibetan fables, it is a story about taming demons, a type of transformation that involves killing and consuming (Dalton 2013).

The tsalung deity is a wrathful form of the Buddha of Compassion, Avalokiteśvara (spyan ras gzigs). The cult of Avalokiteśvara was first popularized in Tibet through the Mani Kabum (Ma ni bka' 'bum), a collection of three treasure texts (gter ma) revealed by three different Treasure revealers (gter ston) from the mid twelfth to thirteenth centuries. They each claimed authorship by King Songtsen Gampo (srong btsan sgam po), and were adopted by both the Kadampa ( $b k a^{\prime}$ dam $p a$ ) and Nyingma sects. The texts focus on the activities of the central figure, Mahākārunika-Avalokiteśvara, and his relationship with religious kings, a narrative that empowered spiritual leaders to take leadership roles in worldly affairs (Dudjom Rinpoche 2002).

The Mani Kabum is a complex orchestration of myth, history, ritual, and a unique meditation system. The Namdroling Khenpos see it as a religious history text (Karma Chakme 2008). The story of Avalokiteśvara and the overwhelming need for his presence in Tibet is told by Karma Chakmé himself in The Melodious Sound of Thunder:

"When Buddha Shakyamuni lay dying, Buddha Amitabha, in the western pure land of Sukhavati, asked the exalted Avalokiteśvara to go to Shakyamuni Buddha and supplicate him not to pass away. Although Amitabha sent Avalokiteśvara with a thousand-petalled golden lotus, when Avalokiteśvara made his plea, the Buddha replied that since he had already tamed the beings he was to tame, he would pass away.

Avalokiteśvara insisted, saying that the Buddha had not walked in the Land of Snows and that the light of his body had not reached Tibet. The Buddha answered, 'That land is not to be subdued by me; it is the land you are to subdue. You should tame the people of Tibet (Karma Chakme 2008)'.

As a syncretic teaching, the Mani Kabum touches upon the Kadampa presentation of compassion and emptiness as two indivisible aspects of enlightened awareness on the Mahāyāna sūtra path. At the same time, it defines the true Mahākārūnika (great compassion) as "the play of intuitive awareness and continuous, fresh gnosis", language distinctly characteristic of the Nyingma tradition. In addition to typical topics such as Buddhist psychology and philosophy, it teaches about "the nine vehicles, the two truths, the Great Seal, Great Perfection, the sequence of the path, the trio of ground, path and result, the trio of view, meditation and action, the three bodies of buddhahood", and more (Kapstein 2002).

By the seventeenth century in the Sky Dharma revelations, the wrathful form of Avalokitśvara took his place as the central figure in yoga practice. This "Corpse-Eating" deity does not have a main role in the other phases of Sky Dharma, the tantric preliminaries or the Great Perfection contemplations. 
In yoga practice, the tsalung deity has three meanings subsumed within the classical trope of outer, inner and secret. According to legend, his outer form arose in reaction to a demonic king of yore name Gurnapa who was violent and harmed many people. The Tibetan way of dealing with such harmful, imposing, and demonic figures is to tame them by manifesting a form more terrifying than that of the demon to be subdued ${ }^{24}$. Thus, Avalokiteśvara manifested himself as this particularly wrathful form in order to liberate Gurnapa and eat his corpse.

Lama Dorje explained that Avalokiteśvara's wrath is not anger, but rather compassionate wrath. When yoga practitioners imagine themselves as this wrathful deity, they should think that all the buddhas' compassion is within. Because of the existence of a universal inner buddha nature, the deity has compassion for each and every sentient being, and at the same time he is there within each person. According to these teachings, these levels of reality are already inseparable with who we are. However, because individuals have so many afflictive emotions, we appear to be different from our compassionate nature. This teaching on karma theory highlights how our true nature as buddhas is obscured by karma and afflictions.

One gives rise to this inner buddha nature in practice via the popular and ubiquitously Tibetan Buddhist method of generation stage (skyed rim) deity yoga (lha yi rnal 'byor). In deity yoga, one visualizes oneself arising in the form of a tantric deity while simultaneously contemplating one's own empty nature. This elaborate visualization is modularized also to appear at the beginning of the tsalung tummo practice.

During retreat time, Lama Dorje told me it is good to perform this visualization of the self as the deity all the time. Penor Rinpoche used to emphasize that the tsalung practitioners should not think that they are performing the exercises, but rather that the deity is performing the exercises through them. For example, when the wrathful Avalokiteśvara raises his hand, practitioners are encouraged to think of one's own hand emitting fire. While performing the exercises, because the psychic heat is rising upward in the central channel, they should imagine themselves as becoming very hot and burning up their karma, obscurations, and afflictions. This compassionate nature of the deity is the method aspect of the practice. In tantric Buddhism, the pair method and wisdom are equally represented in practice. These are the two wings of a bird that carry one to enlightenment, and these themes are actualized in myriad ways according to sect and practice tradition.

In Sky Dharma yoga, the wisdom, or emptiness aspect, comes into play in the inner meaning of the deity. In tsalung practice, one visualizes the outer form of the body as the deity, but the inner area is radiant, empty, and appears as the five colors. As one becomes more experienced with the practice, one comes to see psychic heat (gtum mo) as the emptiness aspect, and the flame as the primordial wisdom that realizes the nature of phenomena. For the wrathful corpse-eating deity, it is the form of the flame, not the outer image of the deity, that consumes the mind's impure karma and obscurations.

The secret meaning of the deity is a completion stage ( $r d z o g s$ rim) technique. Completion stage methods center on the tantric body. The visualization scripted by Migyur Dorje and Karma Chakmé proceeds in stages from the outer form of the deity, to inner heat, and finally to the central channel itself. The practitioner gathers the wind-mind (rlung sems) complex inside the central channel in a visualization, and then the central channel consumes the impure karmic winds. An element of the theory of tantric embodiment common to many Tibetan traditions including the Great Perfection points out that the winds (rlung) and the mind (sems) travel together like a blind horse and a lame rider. Eventually, because of this mutually dependent relationship, through practice, the karmic winds are cleared away and the wisdom winds naturally predominate. When that occurs, enlightenment becomes the natural state.

The meditation script from Sky Dharma prescriptively endows each part of the body with doctrinal qualities. The first meditation begins by seeing oneself arise as the wrathful form of Avalokiteśvara. The deity's body is replete with tantric semiotics. For example, his four fangs symbolize how he conquered four evil spirits. His bodily red color represents his compassionate attachment toward all sentient beings. Such ritual attempts to alter 
associated meaning are common in generation stage tantric techniques. All the while, the practitioner is expected to contemplate the doctrine of emptiness. The simultaneous presence of these three levels of reality-outer, inner, and secret-points out the multivalent truths present in personhood and all manifest reality. While Buddhist philosophy constantly attempts to point out the multivalence of appearances, Tibetan yoga practices aim to draw the practitioner's awareness to the union of relative appearances with the ultimate truth of emptiness. Sky Dharma gives the outer, inner and secret instructions in a single contemplative sequence, thereby combining generation and completion stage practices into a single contemplative technique.

While the deity yoga aspect of tsalung is a generation stage (mahāyoga) practice, the de-personified visualizations of the central channel and the tantric body are completion stage (anuyoga) techniques. Such practices have bliss as the final goal. The mechanism is simply stated: when the central channel has consumed the karmic winds, the result is supreme bliss. For the Great Perfection, the threefold bliss, clarity, and non-conceptuality are the hallmark realizations and are represented by the three main channels. Unlike other yoga systems such as those found in the Gelukpa lineage-including the analog practice of the Six Yogas of Nāropa-here bliss is not the highest state. The Nyingma version of completion stage practices sits within a philosophical milieu that values non-conceptuality as the ultimate realization, rather than bliss.

\section{Fire, Wind, and Breath: Buddhist Cosmology as the Justification for Tibetan Yoga}

Is there something special about the body that gives the physical exercises in yoga a religious or spiritual impact over and above other forms of exercise? While we have seen that these practices are performed in conjunction with deity yoga visualization, they are also supported by karma theory, in particular how karma is embedded throughout the body. The Sky Dharma teachings address this issue about how yoga works relying upon Buddhist doctrine. Locating karma and habitual tendencies (bag chags, Skt. vasanā) within the subtle body positions the body as the primary site for the transformation of the mind. Karma theory in tantric Buddhism provides a physical mechanism and location for the purification of negativity. As the negative karma and habitual tendencies are cleared away, the inner buddha nature that is likewise stored in the body is automatically revealed, and the practitioner should naturally experience realizations.

The afflictions and their seeds-mental habituations (bag chags) - burned in inner heat yoga are the foundation for the formation of the body. Migyur Dorje and many other Tibetan thinkers across the ages have pointed out that the body is made of karma and mental habituations ${ }^{25}$. By burning the seeds of samsāric existence, the practitioner removes the causal conditions for rebirth in samsära, rendering it impossible in the future. If a yogin has performed this practice, at the time of death there will be no karmic seeds to propel them on to a future rebirth, which makes liberation from samsāra inevitable.

The purpose of meditating on heat is to focus the mind inward on fire burning karma. The visualized burning of karma emphasizes the relationship of inner heat yoga to Buddhist cosmology and karma theory. In terms of cosmology, when the practitioner burns up their own karmic seeds, they do so with the understanding that they are cutting themselves off from the source of rebirth in the six realms. Karma theory is integral to how Buddhist cosmology works.

The visualization of fire takes place inside the tummo channel, i.e., the central channel, where the knots—cakra-s-reside. The Sky Dharma cakra system is fivefold, although enumerations of four, six, and seven cakra-s are all common in Tibetan Buddhism ${ }^{26}$. Cakra-s at the crown, throat, heart, navel, and secret place correspond to the five different pure realms. Inside those channels, the seminal essences exist in the shape of five seed syllables, Tibetan letters that correspond to the five buddha families. The five cakra-s also contain six syllables that correspond to the six realms and the six types of beings ${ }^{27}$.

While the mind tends to be focused outwardly on phenomena of the world, the practice draws it inwardly to these inner Buddhist realities. In descriptions of the tantric 
body, even the heart, stomach, intestines, lungs and the rest of the organs correspond to something in the external world. Everything that is external in the world has an internal correlate. In yoga practice, emphasis is given to the presence of holy places such as pilgrimage sites and sacred grounds inside the body.

In this Buddhist vision of reality, there is no difference between the outer and inner worlds. Sky Dharma goes to great lengths to emphasize the inner-outer cosmological paradigm of embodiment. Paraphrasing from Sky Dharma's Vajra Verses, or root verses, one of the Namdroling lamas taught that "Whatever appears out there is the same as what appears inside". As an internal element in the body and an external element in the world, the elements pervade all of material existence and function according to the laws of the natural elements common to both tantra and Tibetan medicine. Yoga practice entails mastery over these internal elements. When that happens, the practitioner will eventually be able to extend that power into the external world. That is why it is common to hear accounts of Tibetan practitioners who are able to control the weather via their control of the elements.

In practice, the inner-outer cosmological reflection so prevalent in tantric traditions is interpreted as, if you do not change what is inside, then the outer world will not change. The teachers at Namdroling explain that the outer universe is a reflection of the inner tantric body. At the crown of the head, a channel corresponds to the formless god realm. The soles of the feet represent the hell realms. The red and white seminal essences from the mother and father are the cause of the outer appearance of the sun and moon. Moreover, without channels, winds, and seminal essences in the body, there would be no outer worldly phenomena, from the gods on down to the bottom of hell. The twenty-four nodes in the body represent the twenty-four places of the dākini. The dakas and dakinis reside in the seminal essences in the channels.

The five elements play a key role here. The inner-outer cosmological reflection theory relies on the fact that the inner makeup of the body and the external world are all made of the same stuff-earth, water, fire, wind, and space. The general problem of samsāra is that people distinguish between outer and inner phenomena, and then become caught up in the world of emotions, straying further away from the experience of non-conceptuality. In reality, if they could identify blood as water, flesh as earth, heat as fire, breath as wind, and space as all-pervasive, including the mind, they would de-personalize their experience and not make such problematic distinctions. The mind is inseparable with seminal essences. Powered by karma, the mind controls all activities, causing a person to create virtue (dge ba) and sin (sdig pa). The latter is the troublemaker and the source of all problems in samsāra.

Inner heat yoga practice unknots the cakra-s, which are obscurations to the perception of these inner-outer realities. While everyone has 9.5 million channels and countless cakra-s, the primary ones are the three main channels and the five cakra-s. The cakra-s are in the shape of a vase wrapped in a net. The throat cakra's channels hang down like threads; the heart cakra's channels are like a ball of thread; the channels at the navel cakra go both up and down.

Unlike many other Tibetan traditions, in Sky Dharma, meditating on the cakra-s is considered dangerous, and an alternative method is taught. This is because if a practitioner moves the winds and seminal essences (bindu) into the wrong place, the knots in the cakra-s could become even tighter, with the risk of creating certain mental or physical problems. Because of the causal relationship between winds, mind, and seminal essences, the mind goes wherever the yogin focuses.

Because of the disadvantages of meditating on the cakra-s, Sky Dharma recommends a cautionary approach to meditating on the cakra-s. They suggest only meditating on the central channel, which is at the center of each of the cakra-s and therefore does the same thing. The teachers at Namdroling point out that while the two side channels roma and kyangma represent bliss and clarity, the central channel represents non-conceptuality, the ultimate goal. They argue that meditating on the central channel includes all three channels and their meanings-bliss, clarity, and non-conceptuality—as well as the three bodies of a Buddha. 
In each posture sequence, the practitioner increases the visualized length of the central channel. For example, by the third postural sequence, the central channel has been extended from below the navel to the navel and up to the heart. The heart cakra has eight primary spokes that split into four each, making thirty-two spokes altogether. By visualizing these, the yogin could potentially increase their wisdom and intelligence and generate realizations. However, if a yogin were to meditate on the heart cakra improperly, they might become mentally ill, unpleasant, uncomfortable, or create a wind disease. The remedy for this is in tune with the Great Perfection's ubiquitous rhetoric of simplicity and ease. One can solely meditate on the central channel, which can only be advantageous and is a condition by which one can generate realizations, increase intelligence, and wisdom.

The Great Perfection's rhetoric of simplicity shows itself again in the ways that certain features of the tantric body model are highlighted in the fourth trulkhor sequence. Here, the visualization of fire reaches up to the throat cakra which has sixteen spokes, or channels. Countless channels branch off from the main channels, and together these comprise the cakra. According to Sky Dharma, if one meditates correctly on the throat cakra, one will spontaneously write poetry and compose beautiful, meaningful texts without learning, effort, or thinking. The Namdroling teachers offer the famous Tibetan yogin Milarepa as an example. When asked for advice, he gave it spontaneously without thinking, and whatever he said was completely in accordance with the dharma. Because of Milarepa's practice of the yoga of inner heat, his words were of immense benefit to others. This is the yogic power of speech, and such persons endowed with it never lie. Ultimately, such a yogin will attain the vajra speech of a Buddha, which was the case for Milarepa.

However, if one improperly focuses on the throat cakra and its spokes, the consequence might be jaundice, becoming deaf and dumb, or simply not being able to speak or concentrate. Therefore, Tulku Migyur Dorje and Karma Chakmé advise that one should simply meditate on the central channel at the level of the throat without the detailed visualization. They claim that the practitioner will gain the same benefits by simply meditating on the throat but not the cakra.

Lama Dorje informed me that the purpose of visualizing fire is that it is a strong force that can make the inner channels open. By jumping in beb ('beb-see next paragraph), or "descents", moving briskly through the dynamic postural sequences, and rubbing the body vigorously within the posture sequences, the wind energy moves, which opens the channels. The force of wind has the ability to untie the knots-the cakra-s.

During the nine years that Lama Dorje studied in the monastic college, in the evenings, he would go to a grove of trees in the middle of the monastery in the same spot where the monks practice tsalung today. There, he practiced his $b e b$-s for an hour after his duties as a student were finished. Beb-s are the most unique and challenging aspect of the tsalung tummo practice, at least for beginners ${ }^{28}$. They consist of jumping up from half lotus and landing on the perineum while holding the breath. Catching air with every part of the body is the mark of success. Like most advanced yoga postures, this maneuver seems impossible at first, but becomes easier with practice.

There are five different types of $b e b$-s in the Sky Dharma yoga sequences. The lamas warn that without breath retention, the maneuver easily leads to injury. I found this advice to be helpful. The most often performed beb is the basic one, a jump up from a seated half-lotus position. The most difficult beb is the dorje (rdo rje; Skt. vajra) beb, where one begins in a standing position, jumps up and into full-lotus position in mid-air, and lands seated in full-lotus. Other $b e b$-s include the circle $b e b$, where one spins around from seated, and the extended $b e b$, where one alternatively jumps and extends each leg. This is why the tsalung practice is executed entirely on a six-inch thick stuffed mat. However, Lama Dorje is so experienced with tsalung that he recounted a story when one time he performed beb-s on a rock in a demonstration.

$B e b$-s are the most rigorous part of tsalung, and I often wondered whether they were meant to clear the mind. It was difficult for me to hold the postural sequence in mind when performing the $b e b$-s. The $b e b$-s require intense physical exertion, and I would often 
forget everything in the process. This is the place where I suspect that physical techniques support states of mind in the most linear fashion.

By the sixth postural sequence in Sky Dharma, the visualized flame reaches the upper part of the central channel, and the practitioner has some experience under their belt. Success is marked by a clear and stable visualization, and the result is that the body becomes quite hot. A sign of success in the yoga of winds, channels and inner heat is that the body might tremble or have uncontrollable impulses, that one's work becomes more efficient, and that one feels less tired. When the practitioner wants to go somewhere, they are able to go quickly. If one were to check the inhalation and exhalation of an advanced practitioner, it would be extremely subtle. Moreover, one's desire for food or clothes will decrease.

Anecdotally, my experience in Ashtanga yoga was useful when we performed the towel-drying test at the end of the retreat. I was among the first to dry the towel despite the fact that I was a beginner to Tibetan yoga. I managed to do that by engaging Ashtanga's trademark "breath with sound" or ujjayi breathing technique. This is merely an anecdote, but it points to the ways that mastery of the body becomes intuitive for yoga practitioners. The monks and nuns were aware that my experience as a yoga practitioner would come in handy during tsalung practice. It was certainly useful to have increased flexibility in my legs and hips compared to most Westerners, which allowed me to sit on the floor all day. However, I did not have an easy time with the postures. While I am physically fit and know how to work with my breath, the tsalung postural sequence bears little resemblance to hatha yoga poses common today. But when it came time to dry the towel on my back, I intuitively knew that performing the breath with sound technique would somehow create an air flow between my skin and the wet sheet.

In this context, heat does not only refer to heat in the body. Heat also refers to bliss. It is therefore possible that some practitioners might only experience mental joy without physically feeling hot. With practice, if one is able to increase the bliss of the mind, and also its clarity, then one will naturally enter into a state of non-conceptuality. Earlier, it was mentioned that the three main channels of the tantric body represent bliss, clarity, and non-conceptuality. The lamas explain that the three work together in a causal process. Bliss, clarity, and non-conceptuality are also called "heat" in this context.

Lama Dorje warned me that I should not expect such results in one month of practice only. You cannot become a real yogin in just one month. At Namdroling, there is an awareness among the monks and nuns that they are just learning these practices. Many aspire for the opportunity in the future to enter into a dedicated retreat environment where they can practice for a longer amount of time.

\section{Conclusions}

The yoga of winds, channels, and inner heat is an example of a physically challenging postural system that is intentionally designed around the transformation of the mind and embedded within a specific religious worldview. The teachers at Namdroling, especially Lama Dorje Wangpo, do much to interpret the text and techniques for practitioners. Throughout our conversations, we discussed many ways that the philosophy and history of Tibetan Buddhism play active roles to support the mental transformation promised by the practice. Three areas stood out that were discussed in this article. First, the history and legacy of the wrathful form of Avalokiteśvara are associated with Sky Dharma yoga, and this is an indispensable component of the practice. Avalokiteśvara, and also the treasure revealer Migyur Dorje, tie Namdroling and its branch institutions to the history and myths of Tibet. Second, when practitioners arise as this deity during yoga practice, this all-consuming inner performance creates the context in which new meaning is assigned to one's body and mind. At the same time, one performs intense physical feats. Visualization, tantric semiotics, and physical performance all work together in tandem to support mental transformation. Third, Tibetan yoga is framed within karma theory and its relationship to Buddhist cosmology. The overall project of Sky Dharma yoga is for practitioners to 
burn their own karmic seeds to stop the cycle of rebirth in the six realms of samsāra. Such religiously framed goals are on one end of a spectrum among modern yoga systems, where the other end might be the physical prowess gained through physical accomplishments.

Funding: Funding for this research was provided by the Fulbright-Hays Doctoral Dissertation Abroad program, as well as from the American Institute of Indian Studies.

Conflicts of Interest: The author declares no conflict of interest.

\section{Notes}

1 Dreyfus points out that it is possible to meditate in a monastery, and that is true. Namdroling has "practice houses" (sgrub khang) for both monks and nuns where they engage in three-year meditation retreat. However, during the course of the lengthy study of Buddhist philosophy, many Tibetan Buddhist monastics do not meditate. Take, for example, Sera Je Gelukpa monastery nearby to Namdroling. Over the course of twenty-five years of training in philosophy, there is little to no training in meditation, although the monks engage in ample rituals. At Namdroling, on the other hand, the Sky Dharma contemplative retreats are offered for one month annually, plus two annual "great accomplishment" (sgrub chen) weeks of practice, summer retreat (yar gnas), which is not particularly contemplative, plus more depending on what is needed. Moreover, I heard several accounts of Namdroling monks and nuns meditating on their own. The monastics are not immune to the influence of Buddhist modernism, and some take up mindfulness or breath meditation in preparation for their future roles as teachers in international dharma centers.

2 When I was at Namdroling, the organizing council of Khenpos were debating whether they should add more time for debate to the monastic college's daily curriculum. There is a sense of pride that the Nyingmapas are as good at debating as the Gelukpas down the street, but also a self-consciousness that they neither spend as much time debating, nor do they use the same curriculum. The Gelukpa monks at Sera Me and Sera Je monasteries, for example, debate the same text for a year. Namdroling's curriculum studies a wide range of texts.

3 This tidbit comes from interviews with Khenpos at Namdroling.

4 This statement is based on interviews and conversations I had while conducting research at Namdroling with various monks and nuns.

5 While the term "Tibetan yoga" is not a neologism (see for example Evans-Wentz 2000), recent popular usage narrows its application to Tibetan Buddhist forms of hatha yoga. Contemporary teachers and scholars such as Dr. Ian Baker and the physician Dr. Nida Chenagtsang are popularizing this usage. At Namdroling, they likewise associated this practice with Indian hatha yoga in oral teachings.

6 I translate gtum mo as "inner heat" because this term has been popularized by contemporary Tibetan teachers such as Lama Yeshe, and also because it is an accurate description of the practice. However, a translation of gtum mo more loyal to the Tibetan language is "fierce woman".

7 While "Tibetan yoga" is a phrase that has been in circulation among scholars of Buddhism since W.Y. Evans-Wentz's publication Tibetan Yoga and Secret Doctrines in 1960 (Evans-Wentz 2000), there has been a resurgence of the term as of late and a new application to postural yoga techniques. Scholars like Ian Baker, Chaoul (Chaoul 2009), and myself all use this term. See Ian Baker, Tibetan Yoga: Principles and Practices (Baker 2019), and (Worth 2020).

8 It would be naïve to assert that Tibet was completely untouched by outside political influences. However, compared to India to the South, Tibetan yoga traditions did not undergo the massive upheaval that Indian yoga traditions underwent due to shifting religious and political influences. In the Land of Snow, the monastic lineages maintained continuity across generations, and the Sky Dharma series of instruction manuals is an example of continuity across centuries.

9 This term was coined by scholar of contemporary yoga Patrick McCartney. I heard it in his talk at the Japan Yocascapes conference in 2018 in Osaka.

10 To be clear, many forms of modern yoga are not relaxing. For example, the practice of Ashtanga yoga in the Mysore tradition is also quite dynamic.

11 I suspect that the Nāth tradition of Hindu yoga is similarly prescriptive. It also centers around fire, although the fire is often external.

12 mKhan po: equivalent to a professor within the monastic system.

13 sLob dpon ma: A female ācārya or teacher. This title is conferred on all graduates of Namdroling's Shedra (monastic college) program. The "ma" suffix indicates that the teacher is a female. This is the highest degree available for women, who at the time of writing are not eligible for the Khenpo degree.

14 When I arrived at Namdroling two months before the start of the annual month-long contemplative retreats, I undertook a miniature version of what the monks and nuns do for years to prepare themselves for Tibetan yoga-I was tutored in Buddhist philosophy. My proclaimed research interest was in the relationship between the body (lus) and mind (sems), so the monks and nuns who took charge of my education had me read a famous epistemology text-Ju Mipham's commentary on Dharmakirti's Treatise on Valid Cognition (rtsad ma rnam 'grel), which has a lengthy section on the relationship between body and mind. Most of the monks and nuns studying that text did not make a connection between it and Tibetan yoga.

15 Out of respect for the teachers, I will continue to use their formal titles throughout the chapter. 
Lama Dorje told me that he carefully went through the text and interpreted the enactment of what is written there. This is what he teaches at Namdroling. Other monastics also contribute to the interpretation of these texts.

17 Ethnographic fieldnotes from Summer 2017.

18 Based on a conversation with a Namdroling Lopon in 2018.

19 Quoted from the (Palyul Ling International 2010, p. 117). Translation modified by the author. This is one of a set of several prayers and recitations read daily during the Sky Dharma retreats.

20 From an interview at Namdroling in March, 2018.

21 February 2018.

22 David Germano pointed this out in an edit to this paper.

23 Inji (ain ji) is the Tibetan word for English that has been used for many years to refer to people of European descent. I got called an inji many times, although I believe the term is decreasing in prevalence as the Tibetan diaspora community becomes more aware of its inaccuracy in applying to all foreigners.

24 Thank you to one of the anonymous reviewers for this explanation.

25 For example, see Longchenpa's Theg mchog rin po che mdzod.

26 For example, in Longchenpa's Theg mchog mdzod, there are four cakra-s.(cite folio page). In the Nyingma School of Tibetan Buddhism, Dudjom Rinpoche enumerates four and six (p. 368). Technically, there are thousands of cakra-s, and what is emphasized here are those most useful for yogic practice.s

27 From formal teachings on Sky Dharma Tsalung Tummo, July 2018.

28 In Ian Baker's Tibetan Yoga, the photos of practitioners in the air with crossed legs are most likely practicing beb-s, either alone or as part of a postural sequence. Additionally, the movie The Yogis of Tibet has great footage of beb-s, among other practices.

\section{References}

Baker, Ian. 2004. The Heart of the World. New York: Penguin.

Baker, Ian. 2019. Tibetan Yoga: Principles and Practices. Vermont: Inner Traditions.

Chaoul, Marco Alejandro. 2009. Magical Movements ('phrul 'khor): Ancient Yogic Practices in the Bon Religion and Contemporary Medical Perspectives. Ph.D. Thesis, Rice University, Houston, TX, USA.

Dalton, Jacob. 2013. The Taming of the Demons: Violence and Liberation in Tibetan Buddhism. New Haven: Yale University Press.

Dreyfus, George. 2003. The Sound of Two Hands Clapping. Berkeley: University of California Press.

Dudjom Rinpoche. 2002. The Nyingma School of Tibetan Buddhism: Its Fundamentals and History. Edited by Gyurme Dorje and Matthew Kapstein. Boston: Wisdom Publications.

Evans-Wentz, Walter Yeerling. 2000. Tibetan Yoga and Secret Doctrines, or Seven Books of Wisdom of the Great Path According to the Late Lama Kazi Dawa-Samdup's English Rendering, 2nd ed. New York: Oxford University Press.

Hatchell, Christopher. 2014. Naked Seeing: The Great Perfection, the Wheel of Time, and Visionary Buddhism in Renaissance Tibet. New York: Oxford University Press.

Higgins, David. 2012. The Philosophical Foundations of Classical rDzogs chen in Tibet: Investigating the Distinction Between Dualistic Mind (sems) and Primordial Knowing (ye shes). Ph.D. Thesis, l'Universite de Lausanne, Lausanne, Switzerland.

Kapstein, Matthew. 2002. The Tibetan Assimilation of Buddhism: Conversion, Contestation and Memory. Oxford: Oxford University Press.

Karma Chakme (Karma chags med.). 2008. The All Pervading Melodious Sound of Thunder: The Outer Liberation Story of Terton Migyur Dorje by Karma Chagme. Translated by Lopon Sonam Tsewang, and Judith Amtzis. Nepal: Nyingma Palyul Retreat Center.

Mallinson, James. 2020. Hathayoga's Early History: From Vajrayāna's Sexual Restraint to Universal Somatic Soteriology. In Hindu Practice. Gavin Flood: Oxford University Press.

McMahon, David. 2009. The Making of Buddhist Modernism. London: Oxford University Press.

Mi 'gyur rdo rje and Kun bzang shes rab. 2007. sNga 'gyur Rgyal ba Dpal yul ba'i ri Chos Gyi Khrid Yig/Khren tu'u: Si khron dpe skrun tshogs pa/si khron mi rigs dpe skrun khang: BDRC W1PD83965. Available online: https://www.tbrc.org/\#!rid=W1PD83965 (accessed on 8 March 2021).

Nida Chenagtsang. 2020. Nejang: Tibetan Self-Healing Yoga. Topanga: Sky Press.

Palyul Ling International. 2010. gNam chos rdzogs chen sangs rgyas lag 'chang gi brgyud ba'i gsol 'debs byin rlabs sprin phung bzhugs so/ in gNamchos zhal 'don bzhugs so/aka Namchö Daily Practice. McDonough: Palyul Ling International.

Samuel, Geoffrey, and Jay Johnston. 2013. Religion and the Subtle Body in Asia and the West: Between Mind and Body. New York: Routledge Studies in Asian Religion and Philosophy.

Skora, Kerry. 2020. The Subtle Body of Vital Presence in Contemplative Practices of Abhinavagupta's Trika Śaivism and Longchenpa's Great Perfection. In Transformational Embodiment in Asian Religions. Edited by George Pati and Katherine Zubko. New York: Routledge.

van Shaik, Sam. 2004. Approaching the Great Perfection: Simultaneous and Gradual Methods of Dzogchen Practice in the Longchen Nyingtig. Boston: Wisdom Publications, p. 98.

Worth, Naomi. 2020. Yoga in Tibet. In The Routledge Handbook of Yoga and Meditation. Edited by Suzanne Newcomb and Karen O'brien-Kop. London: Routledge. 